\title{
Towards a critique of indigenous African religion
}

\author{
Author: \\ Johan Strijdom ${ }^{1}$ \\ Affiliation: \\ ${ }^{1}$ Department of Religious \\ Studies and Arabic, \\ University of South Africa, \\ South Africa \\ Correspondence to: \\ Johan Strijdom \\ email: \\ strijjm@unisa.ac.za \\ Postal address: \\ PO Box 392, Unisa 0003, \\ South Africa \\ Dates: \\ Received: 31 Aug. 2010 \\ Accepted: 09 Oct. 2010 \\ Published: 07 June 2011 \\ How to cite this article: \\ Strijdom, J., 2011, 'Towards \\ a critique of indigenous \\ African religion', HTS \\ Teologiese Studies/ \\ Theological Studies 67(1), \\ Art. \#950, 4 pages. DOI: \\ 10.4102/hts.v67i1.950
}

In this article, it is argued that a postcolonial critique of the colonial study of religion should not preclude a critique of indigenous African religion itself. The latter may be developed from a human rights perspective and a critique of exclusionary views of indigeneity. The argument is illustrated by means of specific case studies.

In his contribution on 'Colonialism' in the Guide to the Study of Religion, David Chidester (2000a) not only offers a brief sketch of the way in which European colonisers since the 16th century invented and used the category of 'religion' to humiliate, exploit and subjugate Africans and other indigenous peoples, but also shows how the 19th century academic study of religion was complicit in this dehumanising project.

From the 16th until the 18th century, European observers denied the existence of religion amongst indigenous 'savages', maintaining that their 'superstitions' contained nothing that were similar to the true religion of Christianity and thereby justified the claim that they 'had no human rights to life, land, livestock or control over their own labor' (Chidester 2000a:428). However, Western scholars in the 19th century of the newly established discipline of Religious Studies did come to acknowledge the existence of religion amongst indigenous peoples but still considered their religion inferior by arguing that it retained animist elements from humankind's earliest (or most 'primitive') stage of evolution. The academic study of religion by means of this classification served European empires in justifying their conquests as a so-called civilising mission.

'This legacy', Chidester (2000b:314, 315, 317) says elsewhere, 'lingers in our current academic enterprises in the study of religion' and must be acknowledged as we develop 'innovative, cutting-edge methods in the history of religion'. Only by coming to terms with this 'horrible history', he insists, would we be 'well positioned to engage critically and creatively with the possibility of new horrible histories that might be on the horizon'.

Towards the end of his essay, Chidester (2000a) offers some remarks on the possibilities that postcolonial theory may open for the future study of religion. He notes that:

in more recent developments within postcolonial theory ... attention has shifted away from the critique of European representations of 'others' to a recovery of the subjectivity and agency of the colonized.

(Chidester 2000a:432-436)

Chidester then maps two opposite positions from which the postcolonial study of religion may proceed, namely indigeneity and hybridity.

At the one extreme are those who speak from an indigenist location. Their aim is to recover and promote pure, authentic pre-colonial roots which they claim have essentially remained the same 'since time immemorial', but were suppressed during the colonial encounter. At the other extreme are those who view culture from a postmodern position of hybridity. This analytical strategy takes historical change seriously and focuses on the diversity and mixture of religious traditions as well as on diaspora communities, which emerged because of the cultural encounters.

Does Chidester raise any critical concerns about these opposing positions? Postcolonial researchers speaking from a position of hybridity should, he emphasises, be aware that not all negotiations are equal (as is abundantly clear from the colonial encounter), whereas indigenists who cultivate a romantic nostalgia for pure, pre-colonial roots will have to contend with historical change and the diversity and mixture of traditions.

He nevertheless distinguishes a group of indigenists who use essentialism as a strategy to recover indigenous traditions that were suppressed by colonialism. Amongst these, he includes (Chidester 2000a:433):

- Fanon as a post-romantic indigenist, who linked the recovery of a suppressed past with his present violent struggle against colonialism. 
- Hindutva which is a term used to describe movements advocating Hindu nationalism and the notion of what constitutes true 'Hinduness' to be recovered and considered as 'the only indigenous religion of India'.

- African movements that reject 'colonial constructions of African mentality' and instead promote 'visions of African humanity and personality, communalism and socialism, in the interests of a postcolonial African renaissance'.

I argued in a previous article that it is at this point that Chidester's sympathetic appraisal of indigeneity should be challenged. The intolerance and violence that exclusionary identities may encourage is amply clear from the construction of religious nationalisms within Hindu, Buddhist, Christian and Islamic traditions, which should alert us to the potential dangers of Afrocentric discourses as well (cf. Strijdom 2009). I will return to the perils of autochthonous discourses and practices in Africa and elsewhere, but would like to clarify first the normative framework within which the debate is to be located.

A dilemma that faces liberal democracies in postcolonial nation states is apparent in instances where a tension exists between traditional cultures on the one hand and modern human rights on the other. In the case of indigenous African religion the problem may be illustrated with reference to the ritual practice of female circumcision (or female genital mutilation) and witchcraft accusations. The question, which Chidester does not address in his essay, is about the ethical content of indigenous religions in comparison with the ethical content of human rights. What critique of postcolonial indigenous African religion should be given, if human rights are taken as the normative point of reference?

Consider, as an example of indigenist idealisation, the presentation of 'female circumcision' in Laurenti Magesa's (1997) African Religion: The moral traditions of abundant life. Magesa's thesis, in short, is that African religion ${ }^{1}$ is an ethical religion that, through its myths and rituals, promotes life, by which is meant communal life that is structured hierarchically not only between the spirit and human realms, but also within the human realm itself (the ancestral spirits are above their living descendants, but so are the elders above the youth). Of the rites of passage, initiation serves to change the status of adolescent boys and girls from childhood to adulthood. During this ritual, they are typically secluded from their families and clans, taught about the traditional tasks expected of men and women and a physical mark is often made on their bodies to remind them of that crucial event in their lives. After the seclusion, they are reintegrated into their groups as adults, now ready to get married with the intent to procreate, that is, to perpetuate life.

1.Magesa (1997:24-27) argues for the term 'African religion' (rather than 'African religions') on the basis of commonalities amongst sub-Saharan groups (i.e. the belief in a Supreme Being, the veneration of ancestral spirits and the centrality of communal existence). Shorter (2010:567), on the other hand prefers the plura communal existence). Shorter (2010:567), on the other hand, prefers the plura 'African religions.' He points out that African theologians (e.g. Mbiti and Idowu) tend to "believe in ... a "super-religion" which purports to belong to all Africans', whereas social anthropologists (e.g. Evans-Pritchard and Mary Douglas) and historian (e.g. Ogot, Kimambo, Ranger and Gray) advocate a more factual and restricted comparative analysis of related African groups. I will use the term 'indigenous African religion' here, which is used by Chidester (2000a) and appropriate to my reflection on indigeneity.
Where male and / or female circumcision is practiced in Africa, Magesa (1997:96-99) explains that the deliberate infliction of intense pain is intended to instil courage amongst the youth, which is a prerequisite to continue the life of the group. In the case of clitoridectomy or the excision or enlargement of the labia' (p. 96) mothers-to-be are thus prepared to bear courageously the pain of childbirth. The ritual, furthermore, binds the circumcised together as a united age-set or agegroup. 'By mingling and sharing their blood by way of the initiation knife, or because they shed it at the same time', he says, 'they become truly brothers and sisters and must be ready to defend one another as brothers and sisters would

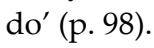

There is no ethical problematisation of the practice by Magesa. It is simply presented as an essential rite that promotes the 'life-force'. Advocates of universal human rights, however, beg to differ. Contrary to Magesa, they would argue that 'female genital mutilation', as they prefer to call the practice, violates the individual woman's right to bodily integrity. It is the right of every woman to decide not to have her body altered in this brutal way. Instead of promoting life, the practice often causes lifelong health problems to women; it should therefore be exposed and criticised as an unjust tradition that needs to be eradicated or modified to cause less potential damage to the quality of women's lives (cf. Salmon 1997). On controversial issues like this, it is argued that researchers have the obligation to take sides (cf. Welsch \& Endicott 2003).

Martha Nussbaum (1999) has addressed the dilemma within a broader context. She opposes those who hold that human rights are a Western construct, which should not be imposed on other cultures, by arguing that such views are often expressed by the dominant voices within a culture that suppress alternative voices. All cultures are heterogeneous and changing. The argument for patriarchal domination often based on religion - was, it must be emphasised, not uncommon a generation or two ago in Western countries, but this asymmetrical relation has been and is being questioned and transformed. The same rational argumentation for conditions that would enable women to pursue a fulfilling life should be applied throughout all nations.

It is therefore clear to Nussbaum that the right to liberty of religion, as enshrined in liberal constitutions, should be limited in cases where religions threaten the well-being of individual women. Where religions are guilty of such practices they should, she proposes as solution, be gently encouraged by liberal states and international human rights organisations (e.g. NGOs [Non-governmental organisations] like Human Rights Watch and Amnesty International) to change their discriminatory ways so that they will eventually conform to the human rights enshrined in their constitutions. The education of reflective, democratic citizens in public schools who engage critically with their traditions rather than submit in blind admiration to them may greatly help towards this end (Nussbaum 1999:116). 
Witchcraft accusations may be taken as a second instance of a conflict between human rights and indigenous African religion. Magesa (1997) describes witchcraft as the main enemy of the life force. In African religion evil that befalls an individual or community is generally explained as caused by a witch, usually an old, unsociable and eccentric woman who is said to have inherited the power to manipulate inherent sinister forces in order to harm her enemies. In order to enforce conformity to traditional communal values and ensure its moral well-being, the afflicted community has no choice but to identify such evil with the help of a diviner and to eliminate it from their midst. According to Magesa (1997):

... witchcraft is intolerable for any society that values ethical principles and life itself ... we can clearly see the role of witchcraft as sanction against immoral behaviour.

If and when a person is convicted of witchcraft, the consequences are invariably grave. The Lamba of Zambia spear a witch to death. The Akamba of Kenya execute proven witches by arrows. Some African communities kill witches by beating or strangling them to death, or by burning them alive. Another form of punishment is banishment from the community, which, in the African conception of human life, is the equivalent of death ...

(Magesa 1997:171-172)

In her introduction to a collection of articles on witchcraft beliefs and accusations ${ }^{2}$ in contemporary Africa (mostly written by African scholars), Gerrie Ter Haar (2007) argues that the victimisation of alleged witches is a human rights issue. The banning or killing of old women and recently of children accused of witchcraft, violates the individual's most basic right to life. She emphasises, however, that the introduction of legislation to suppress witch-hunts would not suffice, unless communities are involved at grassroots level. National legislation that defends and protects the rights of those victimised as witches should certainly not be scrapped. However, education that starts with the traditional worldviews of Africans is imperative; so too is the intervention of NGOs, including religious organisations, which act on behalf of alleged witches. She rightly cautions, though, against Pentecostal Churches that may 'strengthen fears of witchcraft rather than [help] to reduce them' (Ter Haar 2007:26).

My first point then is that Chidester's moral critique of the colonial study of religion should not prevent us from developing a critique of indigenous African religion itself. The discourse of human rights may serve as a 'normative strategy' to engage in this important task (cf. also Hackett 2003:183). We must, of course, remember that the concept of human rights itself should not be essentialised, but that it has a history and is therefore open to continuous

2.Ter Haar (2007) and Ellis (2007) distinguish between beliefs in witchcraft and accusations of witchcraft. They argue that the first need not necessarily lead to witch-hunts (as is clear from the history of witchcraft in early modern and modern Europe), but also concede that a link between the two should in the end not be understated. They, furthermore, distance themselves from the 19th century colonial pejorative application of the term 'witchcraft' to the whole of indigenous African religion (i.e not only to 'witches' as defined earlier, but also to divinous, African religion (i.e. not only to "witches' as defined earlier, but also to diviners, healers etc.), but do no traditionally 'nut it could be used to do good or harm) into one where evil became much more pronounced. They define religion in sub-Saharan Africa as a belief in the existence of an invisible world, distinct but not separate from the visible one, that is home to spiritual beings with effective powers over the material world' (Ellis \& Ter Haar 2007:387; cf. also Ellis \& Ter Haar 2004:14). renegotiation. Although we know it best from the United Nations' (UN) Declaration of Universal Human Rights in 1948, the first generation rights of basic freedoms emerged from the 18th century French and American revolutions, with the second generation of social-economic rights resulting from the 19th century exploitation of industrial workers. The third generation of cultural rights has become prominent only in the past 50 years since postcolonial states have gained independence. Some of these rights are indeed contested and in tension with each other, for example, at what point should freedoms be limited, or would respect for cultural and religious groups inhibit free critical discourse? Thinkers like Amartya Sen and Martha Nussbaum argue that the concept of human rights may have become too vague and therefore propose a list of capabilities ${ }^{3}$ that clarifies the conditions that a state should create to make it possible for all its citizens to live a worthy life. However, this list too remains open for continuous negotiation between cultures and leaves room for culturally specific applications. Other more radical thinkers like Etienne Balibar emphasise that although states have the responsibility to see to the implementation of human rights for their citizens, it is the continuous 'revolt' of activists who resist oppression and exploitation that may help towards this end. ${ }^{4}$

I now return to the dangerous potential of indigenist discourses and practices, when they become exclusionary by drawing the circles of identity ever narrower and rigidly. I will use Peter Geschiere's (2009) The perils of belonging to show how an historically and contextually specific analysis of funerary rituals may help towards a critique of indigenist approaches to culture and religion.

Magesa (1997) considers communality central to the morality of African Religion, contrasting it with Western individualism. This 'guiding principle of African people's ethical behaviour' is well captured, he says, by the term Obuntu (elsewhere also Ubuntu) as the 'quintessence of authentic humanity' and appropriately summarised in the phrase: 'I am, because we are; and since we are, therefore I am' (Magesa 1997:66-67).

But this noble ideal becomes problematic once we begin to study African group formations historically and in specific

3. For one version of her open-ended list of capabilities, see Nussbaum (2007:76-78). Here she discusses the following ten 'central human capabilities' that citizens of a just state should be entitled to: life; bodily health; bodily integrity; senses, imagination and thought; emotions; practical reason; affiliation; other species; play; control over one's environment (political and material). 'A life worthy of human dignity', she argues, would require each and every one of these capabilities. She believes it would be possible to 'gather broad cross-cultural agreement [on these central capabilities], similar to the international agreements that have been reached concerning basic human rights'. She continues: 'Indeed, the capabilities approach is, in my view, one species of a human rights approach, and human rights have often been linked in a similar way to the idea of human dignity'.

4.Cf. Menke (2007) for a discussion of Arendt's critique of the idea of human rights. Arendt $(1949,1955)$ argued, firstly, that human rights are not inalienable, but are always negotiated between human beings and secondly that the concept are always negotiated betw' would be 'nons could see to their implance of continuous dissidence and rights in Arend's thought. Recently Habermas (2010) argued that the moral idea of equal human dignity underlies all human rights, which are continuously and in different contexts to be worked out and specified in the making of laws and to be implemented by political systems. He insists: 'Die Spannung zwischen Idee und Wirklichkeit, die mit der Positivierung der Menschenrechte in die Wirklichkeit selbst einbricht, konfrontiert uns heute mit der Herausforderung, realistisch zu denken und zu handeln, ohne den utopischen Impuls zu verraten. Diese Ambivalenz führt nur zu leicht in Versuchung, sich entweder idealistisch, aber unverbindlich auf die Seite der überschießenden moralischen Gehalte zu schlagen oder die zynische Pose des sogenannten 'Realisten' einzunehmen'. 
locations. Who, we will then need to ask, is included and who is excluded under 'we' in a specific place and time and how do myths and rituals mediate, confirm or challenge such identities?

Geschiere (2009) offers a description of the changes that he has observed over 30 years in funerary rituals in postcolonial Cameroon and interprets their changing form and function within the context of its changing politics. Under Ahmadou Ahidjo's one-party dictatorship in the 1960s and 1970s, citizenship belonged to those who resided within the national borders. All citizens were obliged to stand united behind the leader and to enact their loyalty by means of stiff, compulsory rituals imposed from above. Cultivating local support was strictly forbidden. Traitors were to be identified, renounced and punished. When Paul Biya took over in the early 1980s, he continued the suppression of dissidents, but was forced - due to international political and economic pressure - by the early 1990s to introduce multiparty elections. One of the strategies that Biya used to stay in power was to divide the opposition by actively promoting adherence to one's village of origin and ethnic group. It is within this context that 'at home' funerals started to take on a new significance, becoming the ultimate test of local belonging.

It is not that traditional funerary rituals were not important before the 1990s. Geschiere (1990:190-196) offers a vivid description of their performance that he witnessed in the early 1970s amongst Maka villagers in the southern rainforest of Cameroon. These emotionally intense rituals enacted and mediated kinship roles, between mourning patrilineal descendants on the one hand and joyfully dancing but aggressive in-laws on the other hand. ${ }^{5}$ What happened in the 1990s was that these 'more private rituals increasingly invaded the public sphere, relegating the rituals of nationbuilding to a more or less secondary role' (Geschiere 2009:190). Being buried and attending funerals in one's ancestral village as proof of where one 'really' belonged now came to be used by politicians to cultivate local voters' support along kinship and ethnic lines - contrary to Ahidjo's earlier policy. The consequence of this new autochthonous policy was a continuous fragmentation of collectivities: who was considered to belong 'authentically' and who was to be excluded? Who were autochthons and who were allochthons or strangers within a specific territory?

Geschiere's critique of autochthonous discourse and policies is not limited to postcolonial Cameroon alone. He extends his analysis to similar cases elsewhere in Africa, for example, in the Ivory Coast with Gbagbo's disastrous Opération Nationale d'Identification, in the Eastern Democratic Republic of Congo (DRC) and in South Africa's recent xenophobic outbursts. Most instructively, he includes the indigenist turn in Europe as well, particularly in the Netherlands and in Flanders, but also in France and ancient Athens as the cradle of the discourse.

5.Geschiere (2009:192-196) notes that the Maka proverbially refer to marriage as ' $w a r^{\prime}$ - exogamous marriage by definition means an encounter with another potent illy hostile group. During the funeral, the in laws typically insult the deceased and claim victory by singing songs like ' $n$ ow the vengeance is mine'. The purpose of the ritual is to act out these ambiguities (or 'precarius mixture of ageression and the ritual is to act out these ambiguities (or 'precarious mixture of aggression and solidarity') and make them acting out of the map of kinship and affinity that links persons and groups'.
In all these cases exclusionary, monolithic versions of history and culture are constructed resulting in fragmentation, intolerance and often violence. The task of historical study is to uncover the complex layers of history and to highlight the diversity of voices within any group. This is no trivial relativistic exercise, but a moral duty as explained earlier, to which (I believe) the historical and comparative study of religion may continue to contribute in the search for the social and political well-being of people - not least for people on the continent of Africa.

\section{References}

Arendt, H., 1949, '“The Rights of Man": What are they?', Modern Review 3(1), 24-36. Arendt, H., 1955, 'Die Aporien der Menschenrechte', in H. Arendt (Hrsg.), Elemente und Ursprünge totaler Herrschaft, pp. 601-625, Europäische Verlagsanstalt, Frankfurt am Main. [English title: The perplexities of the Rights of Man (1979)].

Arendt, H., 1979, 'The decline of the nation-state and the end of the rights of man', in The origins of totalitarianism, Part II, Chapter 9, pp. 341-384, Harcourt Brace, New York.

Arendt, H., 2000, The portable Hannah Arendt, Penguin, New York.

Balibar, E., 2007, '(De)constructing the human as human institution: A reflection on the coherence of Hannah Arendt's practical philosophy', Social Research 74(3), the coherenc.

Chabal, P., 2009, Africa: The politics of suffering and smiling, University of KwaZuluNatal Press, Pietermaritzburg.

Chidester, D., 2000a, 'Colonialism', in W. Braun \& R. McCutcheon (eds.), Guide to the study of religion, pp. 423-437, Cassell, London \& New York.

Chidester, D., 2000b, 'Frontier, colonial, and imperial comparative religion', in R. Hackett \& M. Pye (eds.), The history of religions: origins and visions, proceedings of the $18^{\text {th }}$ World Congress of the International Association for the History of Religion, Durban, Roots and Branches, Cambridge, viewed 01 August 2010, from Religion, Durban, Roots and Branches, Cambridge
http://www.iahr.dk/proceedings.html\#Durban

Ellis, S., 2007, 'Witching-times: A theme in the histories of Africa and Europe', in G. Ter Haar (ed.), Imagining evil: Witchcraft beliefs and accusations in contemporary Africa, pp. 31-52, Africa World Press, Trenton, NJ \& Eritrea, Asmara.

Ellis, S. \& Ter Haar, G., 2004, Worlds of power: Religious thought and political practice in Africa. Wits University Press, Johannesburg.

Ellis, S., \& Ter Haar. G., 2007, 'Religion and politics: Taking African epistemologies seriously', Journal of modern African studies 45(3), 385-401. doi: 10.1017/ S0022278X07002674

Geschiere, P., 2009, The perils of belonging: Autochthony, citizenship, and exclusion in Africa and Europe, University of Chicago Press, Chicago.

Habermas, J., 2010, 'Das utopische Gefälle: Das Konzept der Menschenwürde und die realistische Utopie der Menschenrechte', Blätter für deutsche und internationale Politik 8, 43-53, viewed 01 Augustus 2010, from http://www.blaetter.de/archiv/ jahrgaenge/2010/august/das-utopische-gefaelle.

Hackett, R., 2004, 'Human rights: An important and challenging new field for the study of religion', in P. Antes et al. (eds.), New approaches to the study of religion. Vol 2: Textual, comparative, sociological, and cognitive approaches, pp. 165-191, 2: Textual, comparative,
Walter de Gruyter, Berlin.

Magesa, L., 1997, African religion: The moral traditions of abundant life, Kolbe Press, Nairobi.

Menke, C., 2007, "The "Aporias of human rights" and the "One human right": Regarding the coherence of Hannah Arendt's argument', Social Research 74(3), 739-762.

Nyamnjoh, F., 2007, "Ever-dimishing circles": The paradoxes of belonging in Botswana', in M. De la Cadena \& O. Starn (eds.), Indigenous experience today, pp. 305-332, Berg Publishers, Oxford.

Nussbaum, M., 1999, 'Religion and women's human rights', in M. Nussbaum (ed.), Sex and social justice, pp. 81-117, Oxford University Press, New York.

Nussbaum, M., 2006, Frontiers of justice: Disability, nationality, species membership, Harvard University Press, Cambridge.

Salmon, M., 1997, 'Ethical considerations in anthropology and archaeology, or relativism and justice for all', Journal of anthropological research 53(1).

Sen, A., 2005, The argumentative Indian: Writings on Indian history, culture and identity, Farrar, Straus and Giroux, New York.

Sen, A., 2006, Identity and violence: The illusion of destiny, Penguin, London.

Sen, A., 2009, The idea of justice, Penguin, London.

Shorter, A., 2010, 'African religions', in J. Hinnells (ed.), The Penguin handbook of the world's living religions, pp. 564-582, Penguin, London.

Strijdom, J., 2009, 'Nationalizing religion: The violent path of religious nationalism', Alternation 3, 254-269.

Ter Haar, G., 2007, 'Introduction: The evil called witchcraft', in G. Ter Haar (ed.), Imagining evil: Witchcraft beliefs and accusations in contemporary Africa, Africa World Press Trenton, NJ \& Asmara, Eritrea.

Welsch, R. \& Endicoff, K. (eds.) 2003, 'Issue 16: Should anthropologists work to eliminate the practice of female genital mutilation', in R. Welsch \& K. Endicoff (eds.), Taking sides: Clashing views on controversial issues in cultural anthropology, pp. 342-361, McGraw-Hill, Guilford. 